\title{
Eikenella corrodens
}

National Cancer Institute

\section{Source}

National Cancer Institute. Eikenella corrodens. NCI Thesaurus. Code C86351.

A species of facultatively anaerobic, Gram negative, rod shaped bacterium assigned to the phylum Proteobacteria. This species is oxidase positive, catalase, urease and oxidase neg ative, indole neg ative and reduces nitrate. E. corrodens is generally classified as a commensal organism of the mouth and upper respiratory tract but may cause disease in patients with cancer. 